\title{
Product Quality and Price on the Purchase Decision of Hawai Bakery Agents Merauke Products
}

\author{
Nurul Fadilah Aswar ${ }^{\varpi_{1}}$, Muhammad Kadafi Burhanuddin², \& Ifah Finatry Latiep ${ }^{3}$ \\ Magister Management, Faculty of Economics and Business, Hasanuddin University \\ DOI : https://doi.org/10.37531/ecotal.v1i2.12
}

\section{ABSTRACT}

This study aims to determine the effect of product quality on consumer purchasing decisions at Merauke Hawaiian Bread Agent outlets. (2) To determine the effect of price on consumer purchasing decisions at Merauke Hawai Bread Agent outlets. (3) To determine product quality and price have a joint influence on consumer purchasing decisions at Hawai Bakery Agent outlets in Merauke. The approach taken in this study using a quantitative research approach and the population in this study was 4,757 people with a study sample of 94 people. The results showed that product quality partially has a positive and significant effect on purchasing decisions, price partially has a positive and significant effect on purchasing decisions. Simultaneously, the variables of product quality and price have a positive and significant effect on purchasing decisions.

\section{Keywords:}

Product Quality, Price, Service Quality

\begin{abstract}
Abstrak : Penelitian ini bertujuan untuk mengetahui pengaruh kualitas produk terhadap keputusan pembelian konsumen pada gerai Agen Roti Hawai Merauke (2) Untuk mengetahui pengaruh harga terhadap keputusan pembelian konsumen pada gerai Agen Roti Merauke Hawai. (3) Untuk mengetahui kualitas produk dan harga memiliki pengaruh bersama terhadap keputusan pembelian konsumen pada gerai Hawai Bakery Agent di Merauke. Pendekatan yang dilakukan dalam penelitian ini menggunakan pendekatan penelitian kuantitatif dan populasi dalam penelitian ini adalah 4.757 orang dengan sampel penelitian 94 orang. Hasil penelitian menunjukkan bahwa kualitas produk secara parsial berpengaruh positif dan signifikan terhadap keputusan pembelian, harga secara parsial berpengaruh positif dan signifikan terhadap keputusan pembelian. Secara simultan variabel kualitas produk dan harga berpengaruh positif dan signifikan terhadap keputusan pembelian.
\end{abstract}

Kata Kunci : Kualitas Produk, Harga, Kualitas Layanan

$\triangle$ Corresponding Author :

E-mail address: ulfadilahaswar25@gmail.com (Universitas Hasanauddin, Indonesia)

“Received 11 February 2020, Accepted 02 Juny 2020, Published 11 July 2020" 


\section{Introduction}

In marketing its products the company uses a variety of ways to attract consumers and influence consumers in deciding to purchase goods and services. Many companies have the same market segmentation, making the company always innovate in terms of product quality, competitive prices to attract consumers. This competition also occurs in the bakery business sector in the Merauke area. (Kotler and A., Hendra, 2002) say product quality is showing ability that makes consumers feel satisfied when using it. Quality has a direct impact on product or service performance, so quality is closely related to customer value and satisfaction. Factors that also influence consumer purchasing decisions are price. Price is a sensitive factor for consumers because consumers always make various considerations when making purchasing decisions. After consumers observe the promotion of the products offered, by itself consumers will try to choose and compare prices offered by other similar products before the consumer decides to buy the product. Price is one of the determinants of a company's success because the price determines how much profit the company will get from selling its products in the form of goods or services.

Throughout history, price has been a major factor influencing buyers' choices. In recent years, several factors outside prices have become increasingly important. However, price remains one of the most important elements in determining a company's market share and profits (Kotler and Armstrong, 2008). In the city of Merauke there are many culinary companies that sell food products similar to Abon Gulung Cakes such as Lisa bakery at a selling price of Rp. 80,000, hadi bakery at 140,000, Fiona cakes at 90,000. from these data shows intense competition between companies engaged in the bakaery. The price and quality they have is also very competitive in order to get consumers. As a company in the same field, Hawai Bakery has superior products namely original roll floss, tuna, cheese, chicken, sausage, and almod. The distinct advantage of Hawai Bakery is that the quality of its products is guaranteed to be satisfactory and the price is also affordable. These advantages are expected to make consumers feel satisfied. Hawai Bakery comes from the city of Manokwari which was founded in 1983. The consistency held by the company is able to make it more and more attractive to consumers to become a typical culinary from the famous Land of Papua throughout Indonesia and become a mandatory souvenir for tourists visiting the area in Papua. 
On the other hand, Hawai Bakery raises the price of its products every year and prices vary in some places. This might affect consumer purchasing decisions. Even so, the price set by Hawai Bakery is comparable to the quality of the products offered. the purpose of this study is (1) To determine the effect of product quality on consumer purchasing decisions at the Merauke Agent Hawaii outlet. (2) To determine the effect of prices on consumer purchasing decisions at the Merauke Agent Hawaii outlet. (3) To find out product quality and price have a joint influence on consumer purchasing decisions at the Hawai Bakery Agent dealer in Merauke.

\section{Literature Review}

Product quality is an important factor that influences customer satisfaction creation (Pahlawan, 2019). According to (Kotler, 2001) the definition of a product is: "A product is anything that can be offered to a market to satisfy a want or need". Price is the amount of money needed to obtain goods. purchasing decisions are activities of individuals who are directly involved in making decisions to make purchases of products offered by sellers (Ardiansyah, 2013). Decision-making behavior by consumers to purchase products or services begins with awareness of meeting their needs or desires and realizing the next problem, then consumers will take several stages which eventually arrive at the post-buyer evaluation stage (Naninsih, Hardiyono 2019).

It is important to note that the quality of the product is not reviewed by the company standpoint, it is seen from the perspective of the customer (Ismail Razak, 2016). If people think the product specification fits their need, they will be more likely to think the transaction is worthy (Dhanya Alex, 2013). A product that has a quality that meets the standards of quality that have been determined, and quality is a continually changing condition as the consumer's taste, or expectation of a product is always changing (Juwita Magdalena Sitanggang, Sukaria Sinulingga, and Khaira Amalia Fachruddin, 2019). Product quality is product capability including product durability, in easy product packaging and also product usage (Septhani Rebeka Larosa, I Made Sukresna, H.Mudiantono, 2017).

If the product quality meets their expectation, customers tend to regard the online shop as useful and continue to visit it (Laras Putri Handoko, 2016). Product quality is a product or service characteristic that provides the ability to meet customer needs (Tubagus Agus Khoironi, Hidayat Syah, Parlindungan Dongoran, 2018). If a product fulfills the customer"s expectations, 
the customer will be pleased and consider that the product is of acceptable or even high quality (Olise, Moses Chigbata and Ojiaku, Obinna Christian, 2018). The quality of products that are perceived global ratings ranging from bad to good, marked by a high level of abstraction and refers to setting a specific consumption (Neni Oxtafiani and Sri Yuni Widowati, 2017). In value based approach, quality is being defined as the product or services meet the consumers need and wants or expectation (Shaharudin Jakpar Angelyn Goh Sze Na, 2012).

Product quality means that a product meets customer needs leading to customer satisfaction,and quality also means all of the activities in which business engages in, to ensure that theproduct meets customer needs (Priscillia Helena Maria Hidayat, 2015). The product quality is the key issue for the customers - they believe in purchasing a product that will last long (Lawrence Mpele Lekhanya, Henry Lucky Dlamini, 2017).

\section{Method}

The place of this research was carried out on Abon Gulung Hawai Bakery Agent Merauke located at Mopah Airport and the research process took place starting in January-April 2019. The approach taken in this study used a quantitative research approach and the population in this study amounted to 4,757 with samples research amounted to 94 people. As for the operational definition of product quality is a set of characteristics and characteristics of goods and services that have the ability to meet the needs, which is a combined understanding of the reliability, density, convenience, maintenance and other attributes of a product with its indicators 1) Appearance 2) Servings 3) Shape 4) Texture 5) Aroma 6) Taste.

Price is the amount of money distributed for a product or service, or the amount of value spent by customers to get the benefits of owning or using a product or service, with indicators 1) Price set 2) Affordability of prices 3) Price match with quality 4) Price competitiveness.

Purchasing decisions are activities of individuals who are directly involved in making decisions to make a purchase of a product offered by the seller. Stability on a product. with its indicators 1) The habit of buying products. 2) Give recommendations to others. 3) Repurchase As a support in this research, data collection was done by interviewing and distributing questionnaires to respondents, then the data were processed and analyzed using multiple regression analysis methods with the help of SPPS V.20.0 which was operated by computer media. 


\section{Result and Discussion}

Validity test shows the items of each question all the variables $r$ count $>r$ table $=0.30$. according to (Sugiyono, 2016) if $r$ arithmetic $>r$ table $=0.30$; then the statement is valid. So the results of the validity test all questions from each variable are valid.

Reability test show that each variable between the variables of product quality, price, and purchasing decisions turned out to be obtained a Cronbach Alpha value $\geq 0.60$. Thus, the reliability test results for all variables are reliable.

From the results of hypothesis testing shows that the value of the regression coefficient of the independent variables of each independent variable that influences the purchase decision are respectively for product quality of 0.216 , the price of 0.579 while the value of the constant parameter (Constante parameter) of 1,308. Based on these values, the estimated regression model can be formulated in a multiple regression equation as follows:

$$
Y=1,308+0,216 \times 1+0,579 X 2
$$

To find out the influence of product quality, price and on purchasing decisions can be seen from the value of adjusted $\mathrm{R} 2$.

Based on table 4.4 above, it can be seen that the magnitude of the coefficient of determination is indicated by the R Square value of 0.425 which means that the variation of all independent variables namely product quality, price can explain the purchase decision variable by $42.5 \%$ the remaining 57.5\% explained in other variables not proposed in this study. The results of data processing summarized in the results above can then be discussed to determine the effect of the independent variables on the purchase decision variable, which will then be linked to the theory or hypothesis compiled.

\subsection{Effect of Product Quality on Purchasing Decisions at the Merauke Hawai Bakery Outlet} agent

Product quality variables are formed by six indicators, namely Performance, Durability, Conformence to specification, Features (additional privileges), Reliability, Aesthetics. Based on the results of the multiple regression test for the t test for Product Quality variables, it was concluded that Product Quality partially has a positive and significant influence on purchasing decisions. 
Based on the results of the $t$ test for product quality variables, it was concluded that partially Product quality t had a positive and significant influence on purchasing decisions. Based on these results, this study is in line with (Kotler's, 2001) theory which states that product quality is a consumer's perception of the quality or excellence of a product or service in terms of its function relative to other products and supported by research by (Weenas JR., 2013) with the title Effect of product quality, price, promotion and service quality on Spring Bed Comforta purchasing decisions. The analytical tool used in this study is multiple linear regression analysis. The analysis shows that product quality has a positive and significant effect on purchasing decisions.

\subsection{Effect of Prices on Purchasing Decisions on Hawaiian Bakery Oulet Merauke agents}

Price variables are formed by four indicators, namely Price Affordability, Price Conformity with Product Quality, Price Competitiveness, Price Conformity with Benefits. Based on the results of the multiple regression test for the $t$ test for the Price variable, it is concluded that the price partially has a positive and significant influence on purchasing decisions.

Based on these results, this research is in line with the theory stated by Tjiptono in (Weenas, 2013), namely price is one of the determining factors of buyers in determining a purchase decision for a product or service. Price is something that is given in exchange for getting goods or services. Price is a monetary unit or other measure (including other goods or services) exchanged in order to obtain ownership or use rights of an item or service. Price is often used as an indicator of value when the price is associated with perceived benefits or an item or service. It is also supported by research of Hesti Martina Tina (2015) with the title Effect of Analysis of the Influence of Price, Product Quality, and Design on Purchasing Decisions of Honda Motorized Skutermatic Types. The analytical tool used in this study is multiple linear regression analysis. The results of the analysis show that the price variable has a positive and significant influence on purchasing decisions for Honda Motorized Skutermatic Types.

4.3. The Effect of Product Quality on Prices Together Against Purchasing Decisions at the

\section{Merauke Hawai Bakery Outlet agent}

Based on these results, this research is in line with the theory. This finding is in line with the opinion expressed by Kotler, 2001 which states that product quality is the overall characteristics and characteristics of a product or service on the ability to satisfy expressed or implied needs. Product quality reflects the product's ability to carry out its duties including durability, reliability, advancement, strength, ease of packaging, and product separation and other 
characteristics. (Kotler and Armstrong, 2008) also said that the high quality of goods can affect the selling price of an item. Product quality is an identifier for the quality of products that can affect consumers when buying a product. The effect of product quality on consumers when buying products. In addition, this research is in line with the research of (Hesti Ghanimata, F., \& Kamal, M., 2012) with the title Analysis of the influence of price, product quality, and location on purchasing decisions (a study of buyers of milkfish juwana elrina semarang). The analytical tool used in this study is multiple linear regression analysis. The results of the analysis show that the price, product quality and location variables together have a positive and significant influence on purchasing decisions (a study of buyers of milkfish juwana elrina semarang products).

\section{Conclusion}

1) Product quality is partially positive and significant effect on Purchasing Decisions. This is evidenced by the calculated $t$ value greater than the value of the table that is $3.708>1.985$ with a significant level of $0.000<0.05$. Thus Ho is rejected and Ha is accepted.

2) Price is partially positive and significant effect on purchasing decisions. This is evidenced by the calculated $t$ value greater than the $t$ table value of $6.673>1.985$ with a significant level of $0.000<0.05$. Thus Ha is accepted and H0 is rejected.

3) Simultaneously the product quality and price variables have a positive and significant influence on purchasing decisions. This is evidenced by the calculated $\mathrm{F}$ value greater than the $\mathrm{f}$ table 35.158> 2.70 and with a significance level of $0.000<0.05$. Thus Ho is rejected and Ha is accepted.

\section{References :}

Alex, Dhanya. Impact of Product Quality, Service Quality and Contextual Experience on Customer Perceived Value and Future Buying Intentions. European Journal of Business and Management, Vol 3, No.3, 2013.

Ardiansyah. (2013). "The Influence of Product Quality and Brand Image on the Purchase Decision of Drinking Water in Gallon Aqua Packaging in Padang City". management science journal vol. 2 no. 1

Angipora, Hendra. (2002), "The Effect of Product Quality, Brand Image, Price and Promotion on Purchasing Decisions of MPV Type Toyota Kijang Inovva in Semarang". Journal of Management, Vol. 2, No. 3

Basu, Swastha, (2000). Modern Marketing Management. Jakarta: PT. Raja Grafindo Persada. 
Fifyanita Ghanimata Mustafa Kamal, (2012). Analysis of the Effect of Price, Product Quality, and Location on Purchasing Decisions. Management Article from the Diponegoro University Faculty of Economics and Business.

Handoko, Laras Putri. The Effect of Product Quality and Delivery Service on Online Customer Satisfaction in Zalora Indonesia. Jurnal EMBA, Vol.4 No.1 Maret 2016, Hal. 11891199.

Hidayat, Priscillia Helena Maria. The Influence of Product Quality, Price, Storeathmosphere, and Promotion Effectivenesson Consumer Purchase Decision Offlinders Lane Espresso Manado. Jurnal Berkala Ilmiah Efisiensi, Volume 15 No. 05 Tahun 2015.

Jakpar, Shaharudin and Angelyn Goh Sze Na. Examining the Product Quality Attributes That Influences Customer Satisfaction Most When the Price Was Discounted: A Case Study in Kuching Sarawak. International Journal of Business and Social Science, Vol. 3 No. 23; December 2012.

Khoironi, Tubagus Agus dkk. Product Quality, Brand Image and Pricing To Improve Satisfaction Impact on Customer Loyalty. International Review of Management and Marketing, 2018, 8(3), 51-58.

Kotler and Armstrong. (2008). Principles of Marketing. Volume 1 and 2. Issue 12. Jakarta: Erlangga.

Kotler, Philip. (2001). Marketing Management: Analysis, Planning, Implementation and Control. Jakarta: PT. Prehallindo.

Larosa, Septhani Rebeka dkk. Effect of Product Quality, Service Quality, Product Attractiveness and Corporate Image on Decisions Saving on Bima Savings (Study at Bank Jateng Main Branch of Semarang). Faculty of Economics and Business, Diponegoro University: Semarang, 2017.

Lekhanya, , Lawrence Mpele Henry Lucky Dlamini. Customer's Perception Towards Product Quality of Automotive SMEs Operating In Metropolitan Areas, and Consideration of Environmental Impact. Environmental Economics, Volume 8, Issue 1, 2017.

Naninsih, Nur, and Hardiyono. (2019). "Pengaruh Strategi Pemasaran Terhadap Kepuasan Dan Keputusan Pembelian Produk Usaha Kecil Menengah (UKM) 310 Di Makassar" 1 (1): 47-61.

Olise. Effects of Product Quality on Customer Satisfaction: A Review of Manufacturing Company's Performance in Anambra State. International Journal of Business \& Law Research 6(1):39-47, Jan.-Mar., 2018.

Oxtafiani, Neni and Sri Yuni Widowati. Economics \& Business Solutions Journal Volume 1, Number 1, 2017, 35-44.

Pahlawan, Rezha, Abdul Rahman Laba, Erlina Pakki, and Hardiyono Hardiyono. (2019). "Loyalitas Pelanggan Perusahaan Daerah Air Minum ( PDAM ) Kota Makassar" 3 (2): 228-44.

Razak , Ismail. The Impact of Product Quality and Price on Customer Satisfaction with the Mediator of Customer Value. Journal of Marketing and Consumer Research, Vol.30, 2016.

Sitanggang, Juwita Magdalena. Analysis Of The Effect Of Product Quality On Customer Satisfaction And Customer Loyalty Of Indihome ATPT Telkom Regional 1 Sumatera, Medan, North Sumatra, Indonesia. American International Journal of Business Management (AIJBM), Volume 2, Issue 3 (March - 2019), PP 26-37. 